\title{
THE RANDSTAD CASE: MELKI RELOADED? THE FUNDAMENTAL RIGHT TO EFFECTIVE JUDICIAL PROTECTION AS BATTLEGROUND FOR JUDICIAL SUPREMACY IN EUROPEAN LAW
}

\author{
ORLANDO SCARCELLO*
}

\begin{abstract}
This paper will examine the recent preliminary reference to the European Court of Justice issued by the Italian Court of Cassation in the Randstad case, aimed at rearranging the internal constitutional separation between ordinary and administrative courts (article 111(8) of the Constitution). I will first provide some context on both the relations between Italian and EU courts (2.1) and on the confrontation between the Court of Cassation and the Constitutional Court in interpreting article 111 (2.2). I will then specifically examine the referring order to the Court of Justice of the EU (3), focusing on the role of general clauses of EU law as articles 4(3) and 19 TEU and 47 of the Charter in it. Finally, I will consider the instrumental use of EU law made by the Cassation to overcome an unpleasant constitutional arrangement. This aligns Randstad with previous cases such as Melki or A v. B and may foster constitutional conflict in the future.
\end{abstract}

\section{INTRODUCTION}

In this paper I will consider how in the European Union (EU) ordinary judges use supranational law strategically and instrumentally to overturn established domestic provisions, even at the constitutional level. To show how this strategic use might happen, I will consider the Randstad case, ${ }^{1}$ involving the Italian Court of Cassation, the European Court of Justice (ECJ), and the Italian Constitutional Court (the latter indirectly, as a sort of 'stone guest'). This case will show that EU norms safeguarding fundamental rights, in particular the right to effective judicial protection as in articles 19 of the Treaty on European Union (TEU) and 47 of the Charter of Fundamental Rights of the EU (CFREU), can de facto be used strategically by domestic courts to overcome domestic constitutional norms (in Randstad the division of competences between ordinary and administrative courts) independently from the opinion of constitutional courts on the matter. The paper is structured as follows.

First, I will introduce the broader context, stressing how the enlargement of protection of fundamental rights in EU law has fostered an even growing overlap between supranational and domestic guarantees and, therefore, interpretive competition. The wide scope of application of the Charter plays a special role in this inter-legal scenario. I will also situate the judgments within the larger confrontation between the Cassation and the Italian Constitutional Court on the interpretation of article 111(8) of the national Constitution

\footnotetext{
* Postdoctoral Researcher, LUISS Guido Carli, o.scarcello@luiss.it.

${ }^{1}$ Request for a preliminary ruling from the Corte suprema di Cassazione (Italy) lodged on 30 September 2020 (order 19598/20), Case C-497/20 Randstad Italia SpA v Umana SpA and Others, to be decided.
} 
regarding the division of competences ('jurisdiction' in the domestic legal vocabulary) between ordinary and administrative judges.

I will then consider the Randstad preliminary reference ex article 267 of the Treaty on the Functioning of the European Union (TFEU) by the Court of Cassation to show a paradigmatic instance of the role of supranational law in judicial politics.

Finally, it will try to underline that Randstad amounts to a strategic, instrumental, perhaps even abusive use of EU law to overcome domestic internal arrangements. I argue that Randstad follows the path originally shaped by precedents such as Melki in France and $A v . B$ in Austria. Being a preliminary reference issued by a peak court, which are nowadays more and more influential in Luxemburg, and using the now crucial right to effective judicial protection as a pivot to overcome a constitutional provision, it exemplifies a particularly threatening case for the relations between EU and Member State law.

\section{SITUATING RANDSTAD: SUPRANATIONAL AND NATIONAL CONTEXT}

In this paragraph I will situate Randstad within the broader context, examining both the supranational and the national context (2.1). Considering the former, I will mainly focus on the progressive expansion in the scope of application of the Charter of Fundamental Rights and on the subsequent reaction of constitutional courts. The national context, presenting the disagreement between the Cassation and the Constitutional Court on article 111(8) of the Constitution, will be introduced in 2.2.

\subsection{THE SUPRANATIONAL CONTEXT: SUBSTANTIVE OVERLAP OF FUNDAMENTAL RIGHTS IN EUROPE}

The EU and its predecessors, the Communities, were not born endowed with a catalogue of fundamental rights: cases like Stork are famous vestiges of that past. ${ }^{2}$ It is equally known that the lacuna was filled up by the ECJ itself by means of the so called general principles of European law, in turn drawn from the 'common constitutional traditions' of the Member States and from the European Convention on Human Rights. ${ }^{3}$ Despite always rejecting the direct application of domestic norms on rights, ${ }^{4}$ through the general principles, also endowed with horizontal effects, ${ }^{5}$ the Court granted review of rights and appeased disappointed constitutional courts. ${ }^{6}$

Decades later came the Charter of Fundamental Rights: initially aimed at clarifying the rights and making them more visible and certain, with the Lisbon Treaty it added a new tool for judicial review of rights to the arsenal of the ECJ. ${ }^{7}$ It has been object of incremental

\footnotetext{
${ }^{2}$ Case C-1/58 Friedrich Stork \& Cie v High Authority of the European Coal and Steel Community EU:C:1959:4.

${ }^{3}$ Case C-4/73 J. Nold, Koblen- und Baustoffgroßhandlung v Commission of the European Communities EU:C:1974:51; Case C-36/75 Roland Rutili v Ministre de l'intérieur EU:C:1975:137.

${ }^{4}$ Case C-11/70 Internationale Handelsgesellschaft mbH v Einfuhr- und Vorratsstelle für Getreide und Futtermittel EU:C:1970:114.

${ }^{5}$ Case C-144/04 Werner Mangold v Rüdiger Helm EU:C:2005:709.

${ }^{6}$ Bundesverfassungsgericht (BVerfG) Solange I 37, 271 1971; Solange II 73, 339 1983; Italian Constitutional Court (ICC) judgment 183/1973; judgment 170/1984.

${ }^{7}$ Grainne De Búrca, 'The Drafting of the EU Charter of Fundamental Rights' (2001) 26(2) EL Rev 126.
} 
interpretive extension in several directions: the horizontal applicability of some rights ${ }^{8}$ or the discussion on the possible extraterritorial application are cases in point of this tendency. ${ }^{9}$

Most notably, the internal scope of application certifies the ever-growing extension of the Charter. Article 51(1), specifying that the Charter is binding on the institutions and bodies of the Union and on the Member States only when implementing EU law, was initially a source of uncertainty, mainly regarding the meaning of the 'implementation'. For instance, whether it regarded only actions or omissions too was unclear; so was whether Member States derogating from EU law were bound by the Charter. ${ }^{10}$ In 2013 the pivotal Akerberg Fransson and Melloni judgments clarified several points under discussion. ${ }^{11}$ Fransson specified that every time Member State actions fell within the scope of EU law, that action did count as implementation of EU norms by Member States, even when unintended. ${ }^{12}$ Therefore, what did count was not the subjective will of national authorities to implement EU law, but the objective functionality of the enacted provisions to do so, even accidentally. ${ }^{13}$ Later cases mostly confirmed the objective and functional approach of Fransson: although recalled among the various criteria to determine the applicability of the Charter, the aim pursued by domestic authorities was in fact enlisted as one of the criteria to take into account, not as a necessary condition. ${ }^{14}$ In Siragusa and Iida the ECJ enlisted four criteria to establish the applicability of the Charter to Member States action: the intent to implement EU law, the convergence of the aims pursued by States with an objective covered by EU law, the objective impact on EU law, and the existence of specific rules of EU law on the matter. ${ }^{15}$ The Ledra judgment, regarding the ESM treaty, granted the applicability of the Charter to EU institutions and bodies even outside the EU legal framework, provided that the ESM was instrumental to supplement the objectives of the EU. ${ }^{16}$ The Fransson doctrine was to some extent limited in later cases, such as TSN, which allowed Member States to ensure higher standards of rights' protection outside the scope of application of the Charter when adopting opt-outs on the basis of minimum harmonization standards. ${ }^{17}$ Anyhow, the general result of these cases was

\footnotetext{
${ }^{8}$ See the up-to-date analysis by Eleni Frantizou, 'The Horizontal Effect of the Charter: Towards an Understanding of Horizontality as a Structural Constitutional Principle' (2020) 22 Cambridge Yearbook of European Legal Studies 208, 216-220.

${ }^{9}$ Eva Kossoti, 'The Extraterritorial Applicability of the EU Charter of Fundamental Rights: Some Reflections in the Aftermath of the Front Polisario Saga' (2020) 12(2) European Journal of Legal Studies 117; Chiara Macchi, 'With trade comes responsibility: the external reach of the EU's fundamental rights obligations' (2020) 11(4) Transnational Legal Theory (2020) 409, 413-425.

${ }^{10}$ Koen Lenaerts, 'Exploring the Limits of the EU Charter of Fundamental Rights' (2012) 8 European Constitutional Law Review 375.

${ }^{11}$ Case C-617/10 Aklagaren v Hans Akerberg Fransson EU:C:2013:105; Case C-399/11 Stefano Melloni v Ministerio Fiscal EU:C:2013:107.

${ }^{12}$ Filippo Fontanelli, 'Hic Sunt Nationes: The Elusive Limits of the EU Charter and the German Constitutional Watchdog' (2013) 9 European Constitutional Law Review 315, 322-325.

13 ibid 325-327.

${ }^{14}$ Case C-206/13 Cruciano Siragusa v Regione Sicilia - Soprintendenza Beni Culturali e Ambientali di Palermo EU:C:2014:126, para 25.

15 ibid. See also Case C-40/11 Yoshikazu Iida v Stadt Ulm EU:C:2012:691, para 79. The criterion of EU law's specificity is the most used by the Court. See Benedikt Pirker, 'Mapping the Scope of Application of EU Fundamental Rights: A Typology’ (2018) 3(1) European Papers 133, 139-150.

${ }^{16}$ Joined Cases C-8/15 P to C-10/15 P Ledra Advertising Ltd and Others v European Commission and European Central Bank (ECB) EU:C:2016:701, para 67.

${ }^{17}$ Joined Cases C-609 and 610/2017 Terveys- ja sosiaalialan neuvottelujärjestö (TSN) ry v Hyvinvointialan liitto ry and Auto-ja Kuljetusalan Työntekijälittto AKT ry v Satamaoperaattorit ry EU:C:2019:981. See the commentary by Maxime Tecqmenne 'Minimum Harmonisation and Fundamental Rights: A Test-Case for the Identification
} 
an extension in the scope of application of the Charter, encompassing prima facie doubtful cases too. ${ }^{18}$

Fransson must be read together with the twin Melloni judgment: ${ }^{19}$ under the Melloni doctrine, Member States can apply domestic standard on fundamental rights only when these would not undermine the level of protection provided by the Charter and when primacy, direct effect, and uniformity of EU law would be left uncompromised..$^{20}$ As a result, diverging measures at the national level, even when aiming at a higher level of protection, face strict limits.

Read together, Fransson and Melloni entail a strong 'federalizing force': the combination of a widely applicable Charter (Fransson) and of limited room for national constitutional standards (Mellomi) is such that the Charter becomes a wide-ranging standard of judicial review of rights. ${ }^{21}$ As a result, the Charter must be applied frequently and trump national (constitutional) standards of review. Moreover, domestic judges are famously the first guardians of EU law and apply it directly, sometimes after referring a preliminary question to the ECJ (the so called Simmenthal mandate).

Partly as a reaction to Fransson-Melloni, constitutional courts started using the Charter themselves as a yardstick of constitutionality. The broad interpretation of article 51(1) meant that the attempt to functionally separate the Charter and national catalogues of rights (usually at the constitutional level) had failed. Consequently, in a variety of cases two regimes of rights were destined to overlap ('parallel' or 'tandem' applicability). ${ }^{22}$ Although with some differences one another, the list of constitutional courts explicitly relying on the Charter has grown: ${ }^{23}$ after the pioneering experience of Austria, ${ }^{24}$ the cases of Italy ${ }^{25}$ and Germany ${ }^{26}$ aroused particular attention.

of the Scope of EU Law in Situations Involving National Discretion?' (2020) 16 European Constitutional Law Review 493, 500-506 and 510-513.

${ }^{18}$ Eg Joined Cases C-411/10 and C-493/10 N.S. v United Kingdom and M.E. v Ireland EU:C:2011:865, paras 6469 , in which the Charter was considered applicable even to cases in which a certain degree of discretion is left to the Member State in implementing EU law.

${ }^{19}$ See Nikos Lavranos, 'The ECJ's Judgments in Melloni and Akerberg Fransson: Une ménage à trois difficulté' (2013) 4 European Law Reporter 133; Dorota Leczykiewicz, 'The Charter of Fundamental Rights and the EU's Shallow Constitutionalism' in Nicholas W Barber, Maria Cahill and Richard Ekins (eds), The Rise and Fall of the European Constitution (Hart Publishing 2019), 142-143.

${ }^{20}$ Melloni (n 11) paras 55-60. For an exhaustive commentary on Melloni see Aida Torres Pérez, 'Melloni in Three Acts: From Dialogue to Monologue' (2014) 10 European Constitutional Law Review 308.

21 Aida Torres Pérez, 'The federalizing force of the EU Charter of Fundamental Rights' (2017) 15 International Journal of Constitutional Law 1080, 1081-1090.

22 Sara Iglesias Sanchez, 'Article 51: The Scope of Application of the Charter' in Michal Bobek and Jeremias Adams-Prassl (eds), The EU Charter of Fundamental Rights in the Member States (Hart Publishing 2020), 410-412.

${ }^{23}$ European Union Agency for Fundamental Rights, 'Ten Years On: Unlocking the Charter's Full Potential', (2020), 8-9 < https:// fra.europa.eu/sites/default/files/fra_uploads/fra-2020-fundamental-rights-report-2020focus_en.pdf $>$ accessed 3 August 2021.

${ }^{24}$ Verfassungsgerichtshof (VfGH), U 466/11-18, U 1836/11-13. See Andreas Orator, 'The Decision of the Austrian Verfassungsgerichtshof on the EU Charter of Fundamental Rights: An Instrument of Leverage or Rearguard Action?’ (2015) 16 German Law Journal 1429.

${ }_{25}$ ICC, judgment 269/17; judgment 20/19; judgment 63/19. See Giuseppe Martinico and Giorgio Repetto, 'Fundamental Rights and Constitutional Duels in Europe: An Italian Perspective on Case 269/2017 of the Italian Constitutional Court and Its Aftermath' (2019) 15 European Constitutional Law Review 731.

${ }^{26}$ BVerfG Right to Be Forgotten I 1 BvR 16/13; Right to Be Forgotten II 1 BvR 267/17. See Daniel Thym, 'Friendly Takeover, or: the Power of the "First Word". The German Constitutional Court Embraces the Charter of Fundamental Rights as a Standard of Domestic Judicial Review' (2020) 16 European Constitutional Law Review 187. 
On the one hand, the 'appropriation' of the Charter by constitutional courts might be viewed favorably, as constitutional courts would finally be 'taking the Charter seriously'. On the other hand, there is another aim beyond the process of constitutional appropriation: avoiding the risk of being marginalized by the creation of a decentralized system of judicial review of rights performed by ordinary judges. ${ }^{27}$ The widely applicable Charter, directly used by national judges, risks cutting off constitutional courts. Mechanisms like the (rebuttable) presumption of prior application of the German Constitution are explainable as attempts by constitutional courts, the Bundesverfassungsgericht in this case, to resist the process of rights' decentralization. ${ }^{28}$ Comparative analysis shows that in the case of the Italian Constitutional Court, absent a mechanism of individual direct action for constitutional review, the danger of marginalization is even higher. ${ }^{29}$

As a result, the scope of application of EU rights is widening, while constitutional courts in centralized systems of review seem concerned by the risk of de facto decentralization and take steps to avoid that.

In this context of EU rights' expansion, a special role belongs to the right to effective judicial protection, which in the last few years has been at the center of intense judicial elaboration. ${ }^{30} \mathrm{~A}$ series of cases starting from Associação Sindical dos Juizes Portugueses (ASJP) in $2018^{31}$ has clarified that article 47 CFREU must be used to interpret article 19(1) TEU and incorporates in article 19 the requirement of judicial independency. ${ }^{32}$ This allows article 47 to be applied beyond the (already widened) scope of application of the Charter, although only as an interpretive parameter. This line of cases has been summarized and recalled in Repubblika, decided on 20 April 2021, which confirmed article 47 CFREU as a necessary provision to interpret article 19 TEU and judicial independence as in articles 19 TEU and 47 CFREU as an instantiation of the rule of law value as in article 2 TEU. ${ }^{33}$

\footnotetext{
${ }^{27}$ On the centralized/de-centralized divide in constitutional review, see Cheryl Saunders, 'Courts with Constitutional Jurisdiction' in Roger Mastermann and Robert Schütze (eds), The Cambridge Companion to Comparative Constitutional Law (CUP 2019), 417-437.

${ }^{28}$ Dana Burchardt, 'Backlash against the Court of Justice of the EU? The Recent Jurisprudence of the German Constitutional Court on EU Fundamental Rights as a Standard of Review' (2020) 21 German Law Journal 1, 6-8; MW/JHR/MC 'Editorial - Better in Than Out: When Constitutional Courts Rely on the Charter' (2020) 16 European Constitutional Law Review 1, 1-3. For the milder limiting strategy of the VfGH, see Orator (n 24) 1436-1438 and 1442-1444.

${ }^{29}$ Clara Rauchegger, 'National Constitutional Courts as Guardians of the Charter: A Comparative Appraisal of the German Federal Constitutional Court's Right to Be Forgotten Judgments' (2020) 1 Cambridge Yearbook of European Legal Studies 258, 272-275; Clara Rauchegger, 'The Charter as a Standard of Constitutional Review in the Member States' in Michal Bobek and Jeremias Adams-Prassl (eds), The EU Charter of Fundamental Rights in the Member States (Hart Publishing 2020), 489-493.

30 On the evolution of effective judicial protection from a merely procedural to a properly constitutional principle of EU law, see Matteo Bonelli, 'Effective Judicial Protection in EU Law: an Evolving Principle of a Constitutional Nature' (2019) 12 Review of European Administrative Law 35, 37-61.

${ }^{31}$ See Case C-64/16 Associação Sindical dos Juizes Portugueses v Tribunal de Contas (ASJP) EU:C:2018:117, paras 29-37; Case C-284/16 Slowakische Republik. v Achmea BV EU:C:2018:158, paras 32-33; Case C-216/18 PPU LM EU:C:2018:586, para 53; Case C-619/18 European Commission v Republic of Poland EU:C:2019:531, paras 54 and 57; Case C-824/18 A.B. and Others v Krajowa Rada Sadownictwa and Others (A.B.) EU:C:2021:153, paras 115 and 143-146.

32 Matteo Bonelli and Monica Claes, 'Judicial serendipity: how Portuguese judges came to the rescue of the Polish judiciary' (2018) 14 European Constitutional Law Review 622, 633-635; Aida Torres Pérez, 'From Portugal to Poland: The Court of Justice of the European Union as watchdog of judicial independence' (2020) 27(1) Maastricht Journal of European and Comparative Law 105, 109-112.

33 Case C-896/19 Repubblika v Il-Prim Ministru (Repubblika) EU:C:2021:311, paras 47-65.
} 
In its form under article 47 of the Charter, effective judicial protection scores by far as the most mentioned right in preliminary references and amounts under EU law to a sort of 'right to have rights'. ${ }^{34}$ As a matter of fact, when applying EU law domestic judges also are European judges: the norms regarding the organization of the judiciary allow the existence and functioning of institutions that directly connect EU and domestic law. Besides, judges' ability to apply the law independently and freely is a basic requirement of the rule of law in Europe. ${ }^{35}$ Effective judicial protection therefore enjoys a special position among EU rights.

Moreover, as Torres Pérez has noticed, if article 47 is read together with the broad interpretation of the scope of application of the Charter given in Fransson and following cases, it is even possible that 'once a situation is deemed within the fields covered by EU law according to Article 19(1) TEU, for that same reason, it could be argued that the Member States are 'implementing' EU law and thus the Charter applies'. ${ }^{36}$ Therefore, any difference in the scope of application of articles 19 TEU and 47 CFREU might disappear. In the recent Repubblike judgment, ${ }^{37}$ the Court persisted in using article 47 as a criterion to interpret article 19(1) TEU (indirect application), while the larger direct application advocated by Torres Pérez has remained theoretical. However, this further expansion is an option for the future, also since, at least in Repubblika, the distinction between articles 19 TEU and 47 CFREU has been grounded not on the requirement of implementation of EU law (typical of the Charter), but on the line dividing cases in which individual rights are at stake (article 47 CFREU) and cases in which the more general independency of the judiciary is at stake (article 19 TEU). This might further unhook article 47 CFREU from the limits of article 51 CFREU. Finally, and in a similar vein, it has been also argued that article 47 may serve as a specification of one of the values of the EU under article 2 TEU and as such be applied even beyond the scope of EU law, according to the so-called Reverse Solange doctrine. ${ }^{38}$

\footnotetext{
${ }^{34}$ David Reichel and Gabriel N. Toggenburg, 'References for a Preliminary Ruling and the Charter of Fundamental Rights: Experiences and Data from 2010 to 2018' in Michal Bobek and Jeremias AdamsPrassl (eds), The EU Charter of Fundamental Rights in the Member States (Hart Publishing 2020) 467, 471-472 and 475-478.

35 ASJP (n 31) para 36; $L M$ (n 31) paras 50-51.

36 Aida Torres Pérez, 'Rights and Powers in the European Union: Towards a Charter that is Fully Applicable to the Member States?' (2020) 1 Cambridge Yearbook of European Legal Studies 279, 297-298; Torres Pérez 'From Portugal to Poland:' (n 32) 115-118. In a similar vein, Advocate General Tanchev even spoke about a 'constitutional passerelle' between article 19 TEU and 47 of the Charter. See Joined Cases C-585/18, C624/18 and C-625/18 A. K. v Krajowa Rada Sadownictwa EU:C:2019:551, Opinion of AG Tanchev, para 85. The possible extension of Charter rights beyond article 51 of the Charter ex art. 19 TEU recalls similar theoretical possibilities grounded in article $20 \mathrm{TEU}$ (some Charter rights would be applicable beyond art. 51 TEU to avoid limitations to EU citizenship). See Martijn van den Brink, 'The Origins and the Potential Federalising Effects of the Substance of Rights Test' in Dimitry Kochenov (ed), EU Citizenship and Federalism The Role of Rights (CUP 2017), 85, 102-105; José Luís da Cruz Vilaça and Alessandra Silveira 'The European Federalisation Process and the Dynamics of Fundamental Rights' in Kochenov (ed), EU Citizenship and Federalism - The Role of Rights (CUP 2017)125, 138-142.

${ }^{37}$ Repubblika (n 33) paras 35-46 and 52. See also A.B. (n 31) paras 85-89.

38 Armin von Bogdandy and Luke Dimitrios Spieke, 'Protecting Fundamental Rights Beyond the Charter: Repositioning the Reverse Solange Doctrine in Light of the CJEU's Article 2 TEU Case-Law' in Michal Bobek and Jeremias Adams-Prassl (eds), The EU Charter of Fundamental Rights in the Member States (Hart Publishing 2020), 537-538. The concept of 'horizontal Solange' has been proposed to describe the mutual trust between Member States in the EU too. Such trust entails a presumption of conformity of other States' behaviors to EU values. This presumption would be anyway rebuttable and in case of systematic violation of fundamental rights, Member States may suspend horizontal cooperation, especially in the sensitive area of the European Arrest Warrant. See Iris Canor, 'My brother's keeper? Horizontal solange: “An ever closer distrust among the peoples of Europe”" (2013) 2 CML Rev 383; Iris Canor, 'Suspending Horizontal Solange: A
} 
As a result, Randstad must be understood in a context in which the possibility for ordinary judges to affirm their own interpretation of fundamental rights is higher thanks to the existence of an independent and broad system of EU review of rights, even in jurisdictions characterized by a centralized system of review. This risk is particularly high for the right to effective legal protection, which enjoys a special status in quantity (the most used provision in the Charter) and quality (a 'right to have right'). Constitutional courts, on the other hand, progressively internalize the Charter with the goal of avoiding marginalization. Although in limited cases constitutional courts are used to directly apply EU law more in general, ${ }^{39}$ the Charter enjoys the special status of an intrinsically constitutional section of EU law, ${ }^{40}$ to be used simultaneously with national constitutional catalogues.

\subsection{THE NATIONAL CONTEXT: OVERCOMING THE DUAL SYSTEM OF JUDICIAL REVIEW?}

To properly understand Randstad, the national context, namely the domestic dual system of judicial review, must be examined too. The Italian organization of the judiciary follows the French doctrine of a special and separate system of courts to obtain redress against government actors. ${ }^{41}$ The droit administratif, in other words, is mostly adjudicated in a separate system of courts, with regional tribunals as courts of first instance and the Council of State (Consiglio di Stato) as the supreme administrative court.

There are, however, two main differences when comparing the Italian model to the French. First comes the (in)famous concept of 'legitimate interest' describing the legal interest of the individual against the administration to have acts or omissions of the latter reviewed in court. This concept, hardly distinguishable from a special form of legal right, identifies the specific interest that can be preserved by administrative courts, while individual rights stricto sensu shall be brought to ordinary judges. The distinction between legitimate interests (sued in special courts) and individual rights tout court (sued in ordinary courts) is often hard. Thus, the Constitution itself identifies a legal authority to solve possible conflicts between the two jurisdictions (ordinary and special). Here comes the second difference from the classic French model: there is no mixed body in which judges from the two peak courts mingle (as in the Tribunal des Conflits, made of members of the Conseil d'État and of the Cour de Cassation). According to article 111(8) of the Constitution, all conflicts between ordinary and administrative tribunals (conflicts on 'jurisdiction') are solved by the supreme court (Corte di Cassazione) alone. ${ }^{42}$ As a result, the mechanism of judicial review is dual, but not symmetrical. One of the two peak courts, the Court of Cassation, enjoys a certain primacy

\footnotetext{
Decentralized Instrument for Protecting Mutual Trust and the European Rule of Law' in Armin von Bogdandy et al (eds), Defending Checks and Balances in EU Member States (Springer 2021), 183.

${ }^{39}$ David Paris, 'Constitutional courts as European Union courts: the current and potential use of EU law as a yardstick for constitutional review’ (2017) 24(6) Maastricht Journal of European and Comparative Law 792, 799-811.

40 See VfGH U 466/11-18, U 1836/11-13 (n 24) para 5; ICC, 269/2017 (n 25) para 5.2

${ }^{41}$ Francesca Bignami, 'Regulation and the courts: judicial review in comparative perspective' in Francesca Bignami and David Zaring (eds), Comparative Law and Regulation (Edward Elgar 2018), 277-283.

${ }^{42}$ Constitution of the Italian Republic, Article 111(8): 'Appeals to the Court of Cassation against decisions of the Council of State and the Court of Accounts are permitted only for reasons of jurisdiction'. Official English translation available at <https://www.senato.it/documenti/repository/istituzione/costituzione_inglese.pdf $>$ accessed 3 August 2021.
} 
over the Council of State, for it has the power to decide over reasons of jurisdiction. However, clarifying what a reason of jurisdiction is turns out to be rather hard. Moreover, since article $111(8)$ is a constitutional provision, the appropriate interpreter is not the Cassation, but the Constitutional Court. The result of this complex institutional arrangement is a certain degree of interpretive competition between the Cassation and the Constitutional Court on article 111 of the Constitution.

To the extent that this issue of domestic law is relevant here, suffice it to say that in the last years the Court of Cassation has occasionally favored an expansive interpretation of article 111(8). ${ }^{43}$ According to the Cassation, 'jurisdiction' had to be interpreted broadly as referring not only to the norms regarding the establishment and functioning of the judiciary, but also to misguided interpretation of procedural or substantive norms which could de facto deprive plaintiffs and defendants of their rights. ${ }^{44}$ In 2018, the Constitutional Court issued a pivotal decision, judgment $6 / 2018$, which severely restricted this expansive interpretation of article 111(8). According to the Constitutional Court, article 111(8) of the Constitution merely allows the Cassation to censor cases in which administrative tribunals (a.) invade the prerogatives of ordinary courts (or the other way around); (b.) intrude into competences reserved to the legislator or the executive; or (c.) refuse to decide over questions reserved to their competence. Any other case does not belong to the notion of 'jurisdiction': if norms are wrongly interpreted or applied by a court outside the scope of cases enlisted in judgment $6 / 2018$, that must be considered as mere infringement of law (violation de loi). ${ }^{45}$

As a result, the domestic context must be understood considering this confrontation on the notion of jurisdiction and on the interpretation of article 111(8), which entails heavy consequences regarding the possible expansion or restriction of the powers of the Court of Cassation over administrative courts.

The domestic confrontation between the Cassation and the Constitutional Court must be understood by also focusing on the specific attitude of Italian judges towards EU law in general and the Charter in particular. In preliminary rulings between 2010 and 2018, Italian judges have mentioned the Charter more than their peers in other Member States in absolute numbers and score above the European average with respect to the proportion of references that mention it, ${ }^{46}$ but they also collected the highest percentage of dismissals for lack of jurisdiction by the ECJ in the EU (one out of four circa). ${ }^{47}$ Thus, Italian judges seem particularly ready to use the preliminary reference mechanism and the Charter in particular, but are often dismissed by the ECJ. This might reinforce the idea that the Charter is used in a rather nonchalant manner by ordinary judges and confirm the ICC's worry of possible instrumental use of the Charter to overcome unappreciated internal legal arrangements, such

\footnotetext{
43 The 'dynamic' interpretation of article 111(8) of the Constitution is far from being dominant in the Court of Cassation itself. See Pier Luigi Tomaiuoli 'Il rinvio pregiudiziale per la pretesa, ma incostituzionale, giurisdizione unica’ (2020) III Consulta Online, 698, 702-704

$<$ https://www.giurcost.org/studi/tomaiuoli2.pdf> accessed 03 August 2021.

${ }^{44}$ Giuseppe Tesauro, 'L'interpretazione della Corte costituzionale dell'art. 111, ult. comma: una preclusione impropria al rinvio pregiudiziale obbligatorio’ (2020) 34 Federalismi 237, 247-249.

${ }^{45}$ ICC judgment 6/2018, paras 11-15.

${ }^{46}$ See David Reichel and Gabriel N. Toggenburg (n 34). Italian judges fare quite bad in general in preliminary references and are often dismissed by reasoned order, see Arthur Dyevre, Monika Glavina and Michal Ovádek, 'Case selection in the preliminary ruling procedure' (ssrn.com, 9 December 2019), 1, 13-17 <https://papers.ssrn.com/sol3/papers.cfm?abstract_id=3489741> accessed 3 August 2021.

${ }^{47}$ David Reichel and Gabriel N. Toggenburg (n 34) 473.
} 
as the interpretation of article 111(8) of the Constitution. As mentioned in the previous section, a certain centralization of review based on the Charter is happening in other jurisdictions too. In Italy this specifically took the form of a direct message to ordinary judges. While already in previous cases the Constitutional Court referred to the Charter ${ }^{48}$ in 2017 it started using it directly as a parameter of constitutional review and required ordinary judges to reverse the habitual order of references by first referring to Rome and only later to Luxemburg in case fundamental rights' infringement. ${ }^{49}$ The review of the relevant legislation would be performed in the light of both the Constitution and the Charter directly by the ICC. This rule was eventually softened in later cases and turned into a mere suggestion, ${ }^{50}$ but it remarked the ICC's will to engage into autonomous review by means of the Charter.

Briefly, the domestic context shows tense confrontation between the Cassation and the Constitutional Court regarding the interpretation of article 111(8). This confrontation must be also placed in the context of a judiciary quite willful to use EU law in general and the Charter in particular in preliminary references, and of a Constitutional Court visibly worried of the decentralization of review on rights that might follow. The general context, in other words, is tense at the domestic level.

\section{THE PRELIMINARY RULING: ORDER 19598/20}

Given this complex national and supranational context, order 19598/20 (the Randstad order) by the Court of Cassation, submitting three preliminary questions to the Court of Justice, does not come as a surprise.

There is no need to conjecture: by means of the order, the Supreme Court is explicitly trying to overcome decision 6/2018 by the Constitutional Court and looks for help in Luxemburg. When looking at the argument of the Cassation, the right to effective judicial protection is pivotal. Articles 4(3) and 19 TEU, 267 TFEU, 47 CFREU are the backbone on which the order is based. While it is true that Randstand is, after all, a single referring order, it is equally true that empirical studies suggest that preliminary references from peak courts are treated as more important by the ECJ. ${ }^{11}$ Thus, a single order coming from a supreme court as the Cassation is probably more threatening than a bunch coming from lower judges.

Factually, the order comes from an issue in public procurement. A public competitive procedure was called in Region Valle d'Aosta, but the two-stage tender immediately excluded several tenderers based on technical criteria set by the contracting authority. In the second stage, the remaining bids were considered from the financial point of view to select the most economically advantageous. The company Randstad Italia Spa was not admitted to the second stage and challenged the decision in court. The Regional Administrative Tribunal examined two groups of complaints. On the one side, the plaintiff protested the mistaken

\footnotetext{
48 Silvana Sciarra and Angelo Jr Golia, 'Italy: New Frontiers and Further Developments' in Michal Bobek and Jeremias Adams-Prassl (eds), The EU Charter of Fundamental Rights in the Member States (Hart Publishing 2020), 243-249.

49 ICC 269/17 (n 25) para 5. Judgment 269/17 must likely be read together with the equally recentralizing Taricco saga, in which recentralization mainly focused on the supreme principles of the Constitution. See Giovanni Piccirilli, 'The "Taricco Saga": the Italian Constitutional Court continues its European Journey' (2018) 14 European Constitutional Law Review 814, 822-833.

${ }^{50}$ ICC 20/19 (n 25) para 2.3; ICC 63/19 (n 25) para 4.3.

51 Michal Ovádek, Wessel Wijtvliet and Monika Glavina (n 46) 142-153.
} 
technical evaluation of the offer, which led to the exclusion from the second stage. On the other, a series of faults in the second stage were underlined regarding the composition of the evaluating committee, the specification of the criteria to evaluate the financial viability of tenders, and the justification of the final decision. The Regional Administrative Tribunal examined and rejected both groups of complaints. The decision was appealed, and the Council of State rejected the demand again, but this time refused to even consider the second group of complaints, stating that a tenderer excluded in the first stage could only challenge the exclusion (first phase), not the second phase too (other vices). This decision was appealed again, and the appellant asked the Cassation to declare the judgment by the Council of State unlawful as it denied effective judicial protection by refusing to examine the second group of complaints. In fact, according to the appellant, the Cassation, as guardian of the proper division of judicial functions under article 111(8) of the Constitution, was entitled to declare whether the dismissal by the Council of State was valid. The Court of Cassation suspended the proceeding and issued a preliminary ruling to the ECJ asking three separate questions.

With the first question, the Court of Cassation asks whether articles 4(3) and 19(1-2) TEU, and 267 TFEU, 'also read in the light of article 47 of the Charter', are incompatible with a domestic interpretation which does not allow decisions incompatible with the ECJ's judgments on public procurement to be appealed in front of the Court of Cassation. The domestic interpretation is explicitly connected to judgment $6 / 2018$ by the ICC as it allegedly threatens the uniform application and effective judicial protection of EU law.

With the second question, the Cassation asks whether the very same EU provisions are, again, incompatible with a domestic interpretation that prevents appeals to the Cassation of decisions by the Council of State which unlawfully avoid a preliminary reference to the ECJ (beyond the conditions enlisted in CILFIT). ${ }^{52}$ Such interpretation would deprive the ECJ of its role of the guardian of EU legality and threaten the uniform application and effective judicial protection of EU law.

With the third question the Court asks whether under EU law a plaintiff may be prevented from challenging a public competition once it was excluded from participating after a first preliminary stage, also in the light of a series of previous decisions by the ECJ. ${ }^{53}$ The first preliminary question in particular is grounded in rather interesting arguments.

First, the Court of Cassation explicitly asks the ECJ to overcome a national interpretation provided by the Constitutional Court. There is no hidden disagreement between the two courts; on the contrary, the divergence is plainly exposed and the ECJ conceived as a possible external arbiter. The first question is supported by recalling at length the already mentioned domestic conflict on the notion of 'jurisdiction'. By explicitly recalling both article 111(8) of the Constitution and the interpretation given by the ICC in judgment

\footnotetext{
52 Case C-238/81 Srl CILFIT and Lanificio di Gavardo SpA v Ministry of Health EU:C:1982:335, paras 10-20. Famously, the national courts are released from their obligation to refer questions under article 267 TFEU only when the ECJ has already dealt with the point of law or when the interpretation is obvious (so called acte clair). This doctrine has been recently challenged: AG Bobek has proposed the Court to reverse the CILFIT criteria and move from a doctrine aimed at ensuring the correct application of EU law in specific cases to one aimed at granting systematic uniform interpretation. See Case C-561/19 Consorzio Italian Management, Catania Multiservizi SpA v Rete Ferroviaria Italiana SpA EU:C:2021:291, Opinion of AG Bobek, paras 131-180. ${ }^{53}$ Case C-100/12 Fastweb SpA v Arienda Sanitaria Locale di Alessandria EU:C:2013:448; Case C-689/13 Puligienica Facility Esco SpA (PFE) v Airgest SpA (Puglienica) EU:C:2016:199; Case C-333/18 Lombardi Srlv Comune di Auletta and Others EU:C:2019:675.
} 
6/2018, the Court of Cassation is clearly asking the ECJ to declare the duty under EU law to disapply a national constitutional provision, at least as interpreted by the Constitutional Court. For this reason, the Cassation quotes the (in)famous Internationale Handelgesellschaft ${ }^{54}$ and the Taricco $I^{5}$ judgments by the ECJ as justifications of the possible disapplication of the constitutional provision. It is worth noting that the Cassation does not mention the reactions to the two cases, namely the Solange $I^{56}$ decision by the BVerfG after Internationale Handelgesellschaft and order 24/2017 by the Italian Constitutional Court after Taricco I, this way de facto abstracting the two judgments from their rather confrontational context. All in all, this preliminary ruling seems to openly foster constitutional conflict. In fact, what might follow is the Constitutional Court lifting the counter-limits against a decision in Luxemburg accepting the arguments used by the Cassation. ${ }^{57}$ Truly, whether the possible disapplication of article 111(8) would trigger the counter-limits doctrine is not obvious, as Italian lawyers themselves do not agree on that, ${ }^{58}$ but the possibility of open conflict is tangible.

Second, the referring judge draws an abstract distinction between cases in which ordinary judges fail to apply national law in areas under EU competence and cases in which the failure regards areas outside the scope of EU law. Only in the latter case we may speak of infringement of law in the classic sense of continental administrative law (violation de loi): here the judge would be an institution, part of a broader sovereign State, failing to properly perform the judicial function. In the former case, on the other hand, the judge is merely the executor of the EU's will, it acts as a supranational judge. In the material fields conferred to the EU, the State has given up its sovereignty: not even the legislator could regulate them. Thus, when a judge interprets domestic law on public procurement inconsistently with EU law (qua the ECJ's case law), she is not simply infringing the law, she is properly creating new (judicial) law in areas beyond the sovereignty of the State. Therefore, since in this case the judge is creating the law, she is exercising the legislative, not the judicial power. By exercising the power of another branch of government, she runs into the authority of the Court of Cassation (what I have called case b. of judgment 6/2018, see supra at 2.2). The idea that in areas conferred to the EU Member States have given up their sovereign powers and judges merely grant application to EU law is substantiated by referring to a series of decisions by the ECJ, including classic judgments as V an gend en Loos, Costa, Simmenthal, and Opinion 1/91. It does not, however, quote the pivotal Granital decision by the Constitutional Court, which explicitly recognized the autonomy of EU law and the mere effectiveness which national institutions, including judges, were bound to grant it. ${ }^{59}$

Lastly, the classic EU principle of procedural autonomy is recalled, but the Cassation immediately points out that procedural autonomy is limited by the countervailing principles of equivalence and effectiveness. The Cassation suggests that refusing to examine the second group of complaints threatens the uniform application and effectiveness of EU law. The only

\footnotetext{
${ }^{54}$ Internationale Handelsgesellschaft ( $\left.\mathrm{n} 4\right)$.

55 Case C-105/14 Criminal proceedings against Ivo Taricco and Others EU:C:2015:555.

${ }^{56}$ BVerfG 37, 2711971 (n 6).

${ }^{57}$ ICC 183/1973 para 9 (n 6); ICC 170/1984 (n 6) para 7; ICC judgment 24/2017, para 7.

${ }^{58} \mathrm{Eg}$ Roberto Bin argues that counter-limits may be lifted in Randstad. See Roberto Bin, 'È scoppiata la terza

"guerra tra le Corti"? A proposito del controllo esercitato dalla Corte di Cassazione sui limiti della giurisdizione' (2020) Federalismi 1, 8-10. On the other hand, former AG in Luxembourg and former President of the Constitutional Court Giuseppe Tesauro, takes the opposite stance (n 44) 240 and 254. ${ }^{59}$ ICC $170 / 1984$ (n 6) paras 4-5.
} 
remedy under domestic law would be the posthumous and allegedly inadequate action for State liability for breaches of EU law. Effectiveness, meant as judicial effective protection of rights, is the key principle of EU law on which the Cassation relies when trying to overcome the domestic interpretation of article 111(8) of the Constitution.

\section{THE INSTRUMENTAL ROLE EFFECTIVE JUDICIAL PROTECTION}

Randstad is reminiscent of the previous Melki saga, even more so as the Italian Cassation itself quotes the French precedent in the referring order. Melki too was a guerre des judges in which a domestic court, the French Cour de Cassation, asked the Court of Justice about the compatibility with EU law of a domestic constitutional arrangement, namely the constitutional reform introducing the so-called question prioritaire de constitutionnalité. In principle we can see a similar dynamic, with the supreme court reacting to a possible shift of power away from its hands by looking for advice (and support) in Luxemburg. ${ }^{60}$ However, there is a crucial difference in the parameters of review, in the EU provisions that the referring judge uses to try reversing the shift at the domestic level. In Melki, the French Cassation referred to article 267 TFEU to try preventing the new mechanism of preliminary reference to the Constitutional Council from marginalizing its position in the French judiciary. In Randstad, on the other hand, the Italian Cassation relies on a wider series of EU norms, article 267 TFEU being only one of them.

Another case that must be recalled as a precedent is the $A v$. B case decided in $2014{ }^{61}$ After the Austrian Constitutional Court pioneered the appropriation of the Charter by constitutional courts, the Court of Justice was asked by the Austrian Supreme Court whether the EU principle of equivalence required domestic judges to ask the Constitutional Court to quash internal provisions in conflict with the EU Charter (article 47 in that case) instead of simply disapplying it. In a centralized system, after an attempted recentralization on rights' protection by the constitutional court, the supreme court seeks for help in Luxemburg to regain autonomous scrutiny on rights (based on the Charter and the power of disapplication). The Court of Justice answered in the negative: no national legislation or judicial practice could deprive domestic judges of their power (and duty) to refer ex art. 267 TFEU to the Court of Justice, although they remained free to also submit the case to the national constitutional court, even before the preliminary reference. ${ }^{62}$

In all these cases the supreme court attempts overcoming an unpleasant constitutional rule due to either a constitutional reform (Melki) or to the interpretive activity of the constitutional court itself ( $A v . B$ and Randstad); in all three the supreme court looks for help in Luxemburg trying to regain jurisdiction exploiting its status of European judge vis-à-vis centralization in the hands of the constitutional court; in all three the core argument is that

\footnotetext{
${ }^{60}$ Joined cases C-188/10 and C-189/10 Aqiz. Melki and Sélim Abdeli (Melki) EU:C:2010:363. For a commentary of Melki see Arthur Dyevre, 'The Melki Way: The Melki Case and Everything You Always Wanted to Know About French Judicial Politics (But Were Afraid to Ask)' in Monica Claes et al (eds), Constitutional conversations in Europe: actors, topics and procedures (Intersentia 2012), 309-322.

${ }^{61}$ Case C-112/13, Av B and Others EU:C:2014:2195.

62 ibid paras 36-37.
} 
the centralization would risk resizing the powers of the referring judge qua European court and, therefore, the right to effective judicial protection.

Effective judicial protection is pivotal to cases of this kind. Let us consider in more detail the role that effective judicial protection plays in Randstand. The first preliminary question, as previously mentioned, refers to articles 4(3), 19(1-2) TEU, and 267 TFEU, 'also read in the light of article 47 of the Charter'. This wording is not perfectly clear, and the Court does not specify its meaning. Yet, it seems reasonable that it suggests consistent interpretation with article 47 CFREU of the other provisions on effective judicial protection. In other words, given various possible meanings of articles 4(3), 19(1-2) TEU, and 267 TFEU, one should look at article 47 to assess their interpretation. ${ }^{63}$ The Court of Cassation is therefore close to the already mentioned case law (ASJP, Achmea, LM) which uses article 47 CFREU to interpret article 19 TEU. ${ }^{64}$ This also means that, although Randstad is not identical to the cases that motivated judgment 269/2017 (as the potential marginalization of the Constitutional Court in it does not derive from an autonomous use of the Charter), it still relies on the use of article 47 CFREU as an interpretive parameter and it does this in a tense context when it comes to the use of the Charter by domestic judges.

The use of article 4(3) TEU is interesting too, since it underlines the connection between loyal cooperation and effectiveness: in applying EU law, Member States shall cooperate loyally by granting equivalent protection to both domestic and EU rights in an effective manner (the enforcement of the EU right shall not be impossible in practice), and this must happen under the shield of the judiciary. ${ }^{65}$

Finally, the role of article 267 TFEU in the reference deserves a few words. When justifying the first question, the Cassation claims that the effet utile of the preliminary ruling mechanism would be diminished if domestic judges could not disapply national law, including judicial interpretations coming from higher courts, in case of contrast with EU law as interpreted by the ECJ. The Cassation quotes Simmenthal and the more recent Puligienica ${ }^{66}$ to justify the argument about effet utile of article 267 TFEU. In the second question, the Court recalls again article 267 TFEU, although in a slightly different manner. It wonders whether a national interpretation of procedural norms preventing a judge (the Cassation itself) to refer to Luxemburg would conflict with article 267 TFEU when objectively dubious provisions of EU law are involved. ${ }^{67}$ The argument is that domestic judges are unlawfully prevented to perform their function of EU judges (prescribed by article 267 TFEU) by the doctrine enshrined in judgment 6/2018.

\footnotetext{
${ }^{63}$ This would be a particular case of normative hierarchy (an interpretive one) between legal norms which is not new to the case law of the ECJ. Let me recall my own article - Orlando Scarcello, 'On the Role of Normative Hierarchies in Constitutional Reasoning: A Survey of Some Paradigmatic Cases’ (2018) 31(3) Ratio Juris 346, 358-360 for a comment of a similar reasoning in Opinion 2/13.

${ }^{64} \mathrm{It}$ is also worth recalling that article 47 is used as an interpretive criterion also in relation to secondary EU legislation. See Case C-556/17 Alekszij Torubarov v Bevándorlási és Menekültügyi Hivatal EU:C:2019:626, paras 5556.

${ }^{65}$ Case C-33/76 Rewe v Landwirtschaftskammer für das Saarland EU:C:1976:188. See also Herwig Hofmann, 'The Right to an Effective Remedy' in Steve Peers et al (eds), The EU Charter of Fundamental Rights: A Commentary (Hart Publishing 2014), 1211-1212.

${ }^{66}$ Case C-106/77 Amministrazione delle finanze dello Stato v Simmenthal EU:C:1978:49, paras 19-20; Puligienica (n 53) paras 38-39.

${ }^{67}$ It is here that Melki is recalled by the Italian Cassation: Melki stated that such limitations on the power to use the preliminary reference would be illicit and would deprive EU law of its effectiveness. See Melki (n 60) paras 40-45.
} 
As a result, Randstad, even more than its predecessors Melki and $A v . B$, is grounded in all these connective clauses: article 4(3) and 19 TEU, 267 TFEU, 47 of the Charter. It is by using this series of provisions that the Court of Cassation attempts to decentralize the judicial review of (constitutional) rights and circumvent article 111(8) of the Italian Constitution as currently interpreted. It follows that in Randstad we experience an instrumental use of EU law, in particular of effective judicial protection, used as a tool to reach specific internal goals of judicial politics. This holds true independently from the position that the Court of Justice will choose to take on the matter.

An even stronger way to conceptualize Randstad may lie in recalling a venerable concept in continental legal scholarship, the idea of 'abuse of right'. With a certain simplification, a legal right is abused when it is exercised by its holder in a way that is incompatible with the purpose the right was supposed to serve. ${ }^{68}$ Typically, examples regard the use of goods by the owner with the sole aim of damaging their neighbors. Provided that rights include powers and duties, ${ }^{69}$ such as the power/duty to refer to the Court of Justice, the preliminary reference may be, in a specific sense, a power used 'abusively', beyond its original purpose. The Melkistyle reference is of course using the power conferred by article 267 TFEU to ask for clarification on the interpretation of EU law, but the ruling also has a second aim, namely circumventing judgment 6/2018 by the Constitutional Court. Thus, apart from the main aim of article 267 TFEU, namely the clarification of EU law, the reference is also aimed at reaching a rearrangement of internal constitutional boundaries (article 111 of the Constitution) through EU law. This latter goal may well be incompatible with the rationale of article 267 TFEU. Even more so as article 267 TFEU is the key to a mechanism of intercourt dialogue. In the entangled European legal order, in which EU and domestic law are closely connected, the idea of granting due consideration to the various legalities is not new and it has been proposed by scholars, for instance, in the form of the idea of 'constitutional tolerance, ${ }^{70}$ the 'harmonic principles of contrapunctual law', ${ }^{71}$ or the recent idea of interlegality, suggesting that when various legalities are connected, the judge must take into account the entire series of norms potentially applicable to the case at stake and substantively scrutinize them to avoid injustice. ${ }^{72}$ The duty to consider the whole law relevant to the case aims at ensuring the widest examination and justification of the legal reasons applicable to the case. If, however, the norms are recalled not that much with the aim of examining the whole law relevant to the case, but rather having in mind a different goal (eg overcoming or reinterpreting article 111(8) of the Constitution), then the reasoning might well be specious and 'abusive'.

\footnotetext{
${ }^{68}$ On the history and definition of this notion see James Gordley, 'The Abuse of Rights in the Civil Law Tradition' in Rita de la Feria and Stefan Vogenauer (eds), Probibition of Abuse of Law A New General Principle of EU Law? (Hart Publishing 2011), 33-42. On abuse of right in EU law, see Alexandre Saydé, Abuse of EU Law and Regulation of the Internal Market (Hart Publishing 2016), in particular chapters 1 and 3.

${ }^{69}$ Wesley N Hohfeld, 'Some Fundamental Legal Conceptions as Applied on Judicial Reasoning' (1913) 23 Yale Law Journal 16, 28-50.

${ }^{70}$ Joseph Weiler, 'Europe: The Case against the Case of Statehood' (1998) 4 European Law Journal 43, 61-62. ${ }^{71}$ Miguel Poiares Maduro, 'Contrapunctual Law: Europe's Constitutional Pluralism in Action' in Neil Walker (ed), Sovereignty in Transition (Hart Publishing 2003).

72 See Gianluigi Palombella, ‘Theory, Realities, and Promises of Inter-Legality A Manifesto’ in Gianluigi Palombella and Jan Klabbers (eds), The Challenge of Interlegality (CUP 2017), 383; Jan Klabbers, 'Judging InterLegality' in Gianluigi Palombella and Jan Klabbers (eds), The Challenge of Interlegality (CUP 2017), 362.
} 
Of course, the instrumental and perhaps even abusive use of EU law is no novelty. ${ }^{73}$ Studies such as Karen Alter's suggest that one of the key reasons for the success of European legal integration was the use of EU law by national courts in struggles between different levels of the judiciary. ${ }^{74}$ However, the instrumental use of EU law in Randstad deserves special attention because of the different context it takes place in: as previously mentioned, quantitative studies show the current shift of importance of preliminary references from lower to higher courts. ${ }^{75}$ Today, a reference from a peak court is more likely to be considered as 'important' by the Court of Justice (eg assigned to the Grand Chamber or to sections with an Advocate General) than one issued by a lower court. Although according to the same study the Italian Court of Cassation does not fare particularly well when compared to other European counterparts, ${ }^{76}$ a preliminary reference by a high court remains a potentially influential one. Moreover, even if ultimately the reference would be blatantly dismissed by the Court of Justice, the very fact that inter-judicial conflicts like Melki are still present is an interesting finding to be registered.

We do not know what the answer in Luxemburg will be. The ECJ may try to avoid entering a domestic constitutional conflict. For instance, the Court may rely on the idea that manifest errors in the application of EU law, when committed by apex courts like the Council of State, shall be remedied simply through State liability, as expressed by AG Cruz Villalón in Elchinov ${ }^{77}$ differently from what the Italian Cassation thinks. The need to preserve legal certainty and procedural autonomy might be used by the Court of Justice to avoid entering in a tricky internal judicial conflict. This is just an example of the strategies the Court of Justice may use to avoid engaging directly in the interpretation of a delicate provision like article 111(8) of the Constitution and openly challenge the authority of the ICC. However, for the reasons just exposed, the case remains worth analyzing even at this stage: it witnesses the fact that the instrumental use of EU law by domestic judges which made the fortune of EU law is not dead at all. If the Court of Justice will bite, then the possible future reaction from the Constitutional Court will have to be adequately monitored. As a matter of fact, the Court of Justice following the interpretive line proposed by the Cassation would mean the realization of the worst nightmare for a constitutional court: a domestic court (the Cassation) using the EU law (and the ever-expanding Charter), backed by the Court of Justice, to overcome the current interpretation of the Constitution and follow an independent policy of rights' interpretation. What constitutional courts in Austria, Italy, and Germany consistently tried to avoid in the last few years might happen despite their efforts. Reactions to these

\footnotetext{
${ }^{73}$ Remaining in the context of Italy, consider the Kamberaj case (Case C-571/10 Servet Kamberaj v Istituto per l'Edilizia Sociale della Provincia autonoma di Bolzano and Others EU:C:2012:233), an attempt by the referring judge to overcome even the national supreme constitutional principles through EU law and dismissed by the Court as merely hypothetical (paras 44-46).

${ }^{74}$ Karen Alter, 'Explaining National Court Acceptance of European Court Jurisprudence: A Critical Evaluation of Theories of Legal Integration' in Anne Marie Slaughter, Alec Stone Sweet, Joseph Weiler (eds), The European Court and National Courts: Doctrine \& Jurisprudence: Legal Change in its Social Context (Hart Publishing 1998), 241-246; Karen Alter, Establishing the Supremacy of European Law (OUP 2001), 45-60; Karen Alter, 'The European Court's Political Power Across Time' and Space, in Karen Alter, The European Court's Political Power (OUP 2009).

${ }^{75}$ Michal Ovádek, Wessel Wijtvliet and Monika Glavina (n 46)142-153.

76 ibid 150-153.

77 Case C-173/09 Georgi Ivanov Elchinov v Natsionalna zdravnoosiguritelna kasa EU:C:2010:336, Opinion of AG Pedro Cruz Villalón, paras 23-40.
} 
possible scenarios include the use of the counter-limits doctrine and a new constitutional clash after the ultra vires declaration in Weiss-PSPP.

\section{CONCLUSION}

In this paper I have considered the Randstad case. The Italian Court of Cassation has looked for help in Luxemburg to solve an internal struggle on the interpretation of a particularly complex constitutional provision, article 111(8) of the Constitution. The reference has happened in an era of tensions: while the use of the Charter by ordinary judges grows, the risk of being sidestepped is more and more perceived by constitutional courts, some of which are reacting by internalizing the Charter. Article $47 \mathrm{CFREU}$, and effective judicial protection more in general, are key norms in this process. In Randstad, the Italian Court of Cassation is in fact using effective judicial protection to circumvent the Constitutional Court's interpretation of article 111(8) Const.

We still do not know what the result of this reference will be. The ECJ may try to avoid entering the internal division of powers between the two courts, this way neutralizing the possible conflict. After all, despite the quite peculiar organization of the judiciary in Italy, with a dual system of review based on the rather puzzling divide between rights and legitimate interests, still one may say that the independency of the judiciary is not under threat, nor the individual protection of rights in courts systematically threatened. The other way around, it may support the reference and bring about another Taricco saga, possibly ending with the ICC lifting the counter-limits.

However, no matter the result of the saga, the Randstad reference resembles an instrumental use of EU law to solve internal disagreements between courts, in a way that recalls and perhaps overshadows cases like Melki and $A v$. B. Depending on the reaction of domestic constitutional courts, however, interpretive competition through EU law, suggested by Alter as an explanation for its success, may become a danger for its previous beneficiary. 


\section{LIST OF REFERENCES}

Alter K, 'Explaining National Court Acceptance of European Court Jurisprudence: A Critical Evaluation of Theories of Legal Integration' in Slaughter A M, Stone Sweet A, Weiler J (eds), The European Court and National Courts: Doctrine \& Jurisprudence: Legal Change in its Social Context (Hart Publishing 1998)

DOI: $10.5040 / 9781472561909 . c h-008$

Alter K, Establishing the Supremacy of European Law (OUP 2001)

Alter K, The European Court's Political Power (OUP 2009)

Bignami F, 'Regulation and the courts: judicial review in comparative perspective' in Bignami F and Zaring D (eds), Comparative Law and Regulation (Edward Elgar 2018) DOI: https://doi.org/10.4337/9781782545613.00022

Bin R, 'È scoppiata la terza “guerra tra le Corti”? A proposito del controllo esercitato dalla Corte di Cassazione sui limiti della giurisdizione’ (2020) Federalismi 1

Bonelli M and Claes M, 'Judicial serendipity: how Portuguese judges came to the rescue of the Polish judiciary' (2018) 14 European Constitutional Law Review 622

DOI: https://doi.org/10.1017/S1574019618000330

Bonelli M, 'Effective Judicial Protection in EU Law: an Evolving Principle of a Constitutional Nature' (2019) 12 Review of European Administrative Law 35

DOI: $10.7590 / 187479819 X 15840066091240$

Burchardt D, 'Backlash against the Court of Justice of the EU? The Recent Jurisprudence of the German Constitutional Court on EU Fundamental Rights as a Standard of Review' (2020) 21 German Law Journal 1

DOI: https://doi.org/10.1017/glj.2020.16

Canor I, 'My brother's keeper? Horizontal solange: "An ever closer distrust among the peoples of Europe”' (2013) 2 Common Market Law Review 383

Canor I, 'Suspending Horizontal Solange: A Decentralized Instrument for Protecting Mutual Trust and the European Rule of Law' von Bogdandy A et al (eds), Defending Checks and Balances in EU Member States (Springer 2021)

DOI: https://doi.org/10.1007/978-3-662-62317-6 8

da Cruz Vilaça L and Silveira AJ, 'The European Federalisation Process and the Dynamics of Fundamental Rights' in Kochenov D (ed), EU Citizenship and Federalism - The Role of Rights (Cambridge University Press 2017) 
De Búrca G, 'The Drafting of the EU Charter of Fundamental Rights' (2001) 26(2) European Law Review 126

Dyevre A, 'The Melki Way: The Melki Case and Everything You Always Wanted to Know About French Judicial Politics (But Were Afraid to Ask)' in Claes M et al (eds), Constitutional conversations in Europe: actors, topics and procedures (Intersentia 2012)

Fontanelli F, 'Hic Sunt Nationes: The Elusive Limits of the EU Charter and the German Constitutional Watchdog' (2013) 9 European Constitutional Law Review 315 DOI: https://doi.org/10.1017/S1574019612001162

Frantizou E, 'The Horizontal Effect of the Charter: Towards an Understanding of Horizontality as a Structural Constitutional Principle' (2020) 22 Cambridge Yearbook of European Legal Studies 208

DOI: https://doi.org/10.1017/cel.2020.7

Gordley J, 'The Abuse of Rights in the Civil Law Tradition' in de la Feria $\mathrm{R}$ and Vogenauer S (eds), Probibition of Abuse of Law A New General Principle of EU Law? (Hart Publishing 2011)

DOI: $10.5040 / 9781472565570 . c h-004$

Hofmann H, 'The Right to an Effective Remedy' in Peers S et al (eds), The EU Charter of Fundamental Rights: A Commentary (Hart Publishing 2014)

DOI: $\underline{10.5040 / 9781849468350 . c h-050}$

Hohfeld WN, 'Some Fundamental Legal Conceptions as Applied on Judicial Reasoning' (1913) 23 Yale Law Journal 16

DOI: https://doi.org/10.2307/785533

Iglesias Sanchez S, 'Article 51: The Scope of Application of the Charter' in Bobek M and Adams-Prassl J (eds), The EU Charter of Fundamental Rights in the Member States (Hart Publishing 2020)

DOI: $10.5040 / 9781509940943 . c h-0021$

Klabbers J, 'Judging Inter-Legality' in Palombella G and Klabbers J (eds), The Challenge of Interlegality (CUP 2017)

DOI: https://doi.org/10.1017/9781108609654.015

Kossoti E, 'The Extraterritorial Applicability of the EU Charter of Fundamental Rights: Some Reflections in the Aftermath of the Front Polisario Saga' (2020) 12(2) European Journal of Legal Studies 117

DOI: 10.2924/EJLS.2019.022 
Lavranos N, 'The ECJ's Judgments in Melloni and Akerberg Fransson: Une ménage à trois difficulté' (2013) 4 European Law Reporter 133

Leczykiewicz D, 'The Charter of Fundamental Rights and the EU's Shallow Constitutionalism' in Barber N W, Cahill M and Ekins R (eds), The Rise and Fall of the European Constitution (Hart Publishing 2019)

Lenaerts K, 'Exploring the Limits of the EU Charter of Fundamental Rights' (2012) 8 European Constitutional Law Review 375

DOI: https://doi.org/10.1017/S1574019612000260

Macchi C, 'With trade comes responsibility: the external reach of the EU's fundamental rights obligations' (2020) 11(4) Transnational Legal Theory (2020) 409

DOI: $\underline{\text { https://doi.org/10.1080/20414005.2020.1859255 }}$

Martinico G and Repetto G, 'Fundamental Rights and Constitutional Duels in Europe: An Italian Perspective on Case 269/2017 of the Italian Constitutional Court and Its Aftermath' (2019) 15 European Constitutional Law Review 731

DOI: https://doi.org/10.1017/S1574019619000397

MW/JHR/MC, 'Editorial - Better in Than Out: When Constitutional Courts Rely on the Charter', (2020) 16 European Constitutional Law Review 1

DOI: https://doi.org/10.1017/S1574019620000061

Orator A, 'The Decision of the Austrian Verfassungsgerichtshof on the EU Charter of Fundamental Rights: An Instrument of Leverage or Rearguard Action?' (2015) 16 German Law Journal 1429

DOI: https://doi.org/10.1017/S2071832200021209

Palombella G, 'Theory, Realities, and Promises of Inter-Legality A Manifesto' in Palombella G and Klabbers J (eds), The Challenge of Interlegality (CUP 2017)

DOI: https://doi.org/10.1017/9781108609654.016

Paris D, 'Constitutional courts as European Union courts: the current and potential use of EU law as a yardstick for constitutional review’ (2017) 24(6) Maastricht Journal of European and Comparative Law 792

DOI: https://doi.org/10.1177/1023263X17747232

Piccirilli G, "The "Taricco Saga": the Italian Constitutional Court continues its European Journey' (2018) 14 European Constitutional Law Review 814

DOI: https://doi.org/10.1017/S1574019618000433

Pirker B, 'Mapping the Scope of Application of EU Fundamental Rights: A Typology' (2018) 3(1) European Papers 133

DOI: $\underline{10.15166 / 2499-8249 / 203}$ 
Poiares Maduro M, 'Contrapunctual Law: Europe's Constitutional Pluralism in Action' in Walker N (ed), Sovereignty in Transition (Hart Publishing 2003)

DOI: $10.5040 / 9781472562883 . c h-021$

Rauchegger C, 'National Constitutional Courts as Guardians of the Charter: A Comparative Appraisal of the German Federal Constitutional Court's Right to Be Forgotten Judgments' (2020) 1 Cambridge Yearbook of European Legal Studies 258 DOI: https://doi.org/10.1017/cel.2020.13

Rauchegger C, 'The Charter as a Standard of Constitutional Review in the Member States' in Bobek M and Adams-Prassl J (eds), The EU Charter of Fundamental Rights in the Member States (Hart Publishing 2020)

DOI: $10.5040 / 9781509940943 . c h-0025$

Reichel D and Toggenburg G N, 'References for a Preliminary Ruling and the Charter of Fundamental Rights: Experiences and Data from 2010 to 2018' in Bobek M and AdamsPrassl J (eds), The EU Charter of Fundamental Rights in the Member States (Hart Publishing 2020)

DOI: 10.5040/9781509940943.ch-0024

Saunders C, 'Courts with Constitutional Jurisdiction' in Mastermann R and Schütze R (eds), The Cambridge Companion to Comparative Constitutional Law (CUP 2019) DOI: https://doi-org.proxy.library.nyu.edu/10.1017/9781316716731.017

Saydé A, Abuse of EU Law and Regulation of the Internal Market (Hart Publishing 2016)

Scarcello O, 'On the Role of Normative Hierarchies in Constitutional Reasoning: A Survey of Some Paradigmatic Cases' (2018) 31(3) Ratio Juris 346

DOI: https://doi.org/10.1111/raju.12220

Sciarra S and Golia A, 'Italy: New Frontiers and Further Developments' in Bobek M and Adams-Prassl J (eds), The EU Charter of Fundamental Rights in the Member States (Hart Publishing 2020)

DOI: $10.5040 / 9781509940943 . c h-0011$

Tecqmenne M, 'Minimum Harmonisation and Fundamental Rights: A Test-Case for the Identification of the Scope of EU Law in Situations Involving National Discretion?' (2020) 16 European Constitutional Law Review 493

DOI: https://doi.org/10.1017/S1574019620000255

Tesauro G, 'L'interpretazione della Corte costituzionale dell'art. 111, ult. comma: una preclusione impropria al rinvio pregiudiziale obbligatorio' (2020) 34 Federalismi 237 
Thym D, 'Friendly Takeover, or: the Power of the "First Word". The German Constitutional Court Embraces the Charter of Fundamental Rights as a Standard of Domestic Judicial Review' (2020) 16 European Constitutional Law Review 187 DOI: https://dx.doi.org/10.1017/S1574019620000127

Tomaiuoli PL, 'Il rinvio pregiudiziale per la pretesa, ma incostituzionale, giurisdizione unica' (2020) III Consulta Online available at

$<\underline{\text { https://www.giurcost.org/studi/tomaiuoli2.pdf }>}$

Torres Pérez A, 'From Portugal to Poland: The Court of Justice of the European Union as watchdog of judicial independence' (2020) 27(1) Maastricht Journal of European and Comparative Law 105

DOI: https://doi.org/10.1177/1023263X19892185

Torres Pérez A, 'Rights and Powers in the European Union: Towards a Charter that is Fully Applicable to the Member States?' (2020) 1 Cambridge Yearbook of European Legal Studies 279

DOI: https://doi.org/10.1017/cel.2020.8

Torres Pérez A, 'The federalizing force of the EU Charter of Fundamental Rights' (2017) 15 International Journal of Constitutional Law 1080

DOI: https://doi.org/10.1093/icon/mox075

Torres Pérez A, 'Melloni in Three Acts: From Dialogue to Monologue' 10 European Constitutional Law Review (2014) 308

DOI: https://doi.org/10.1017/S1574019614001199

van den Brink M, 'The Origins and the Potential Federalising Effects of the Substance of Rights Test' in Kochenov D (ed), EU Citizenship and Federalism - The Role of Rights (CUP 2017)

DOI: https://doi.org/10.1017/9781139680714.004

von Bogdandy A and Dimitrios Spieke L, 'Protecting Fundamental Rights Beyond the Charter: Repositioning the Reverse Solange Doctrine in Light of the CJEU's Article 2 TEU Case-Law' in Bobek M and Adams-Prassl J (eds), The EU Charter of Fundamental Rights in the Member States (Hart Publishing 2020)

DOI: $10.5040 / 9781509940943 . c h-0027$

Weiler J, 'Europe: The Case against the Case of Statehood' (1998) 4 European Law Journal 43

DOI: https://doi.org/10.1111/1468-0386.00042 